〔第12回放射線技術シンポジウム】 10．循環器救急疾患における断層心エコー法の有用性について（遠藤・他）

〔第12回放射線技術シンポジウム〕

\title{
10．循環器救急疾患における断層心エコ一法の有用性について
}

大垣市民病院放射線科

遠藤斗紀雄・安田鋭介・金森勇 雄

Key words: Two dimensional echocardiogram (2DE), Cardiac emergency

\section{CLINICAL USEFULNESS OF TWO DIMENSIONAL ECHOCARDIOGRAM DURING CARDIAC EMERGENCY}

\author{
TOKIO ENDO, EISUKe YASUdA and ISAO KANAMORI \\ Department of radiology, Ogaki Municipal Hospital
}

\begin{abstract}
Summary
In the present study, we investigated the clinical usefulness of emergency $2 \mathrm{DE}$ in patients with AMI with or without complications, myocarditis, and SBE.

The results were as foffows: 1) 2DE was useful in the early diagnosis of subendocardial infarctions associated with bundle brlanch block, where ECG was not useful in detecting AMI. 2) The complications of AMI, such as interventricular septal perforation, free wall rupture, and tend \# on rupture, could be easily and promptly be diagnosed by 2DE. 3) $2 \mathrm{DE}$ was able to give information about the extent and the degree of the valvular lesions impaired by SBE, which was necessary for surgical treatment. 4) Myocarditis brought about myocardial inflammatory edema and asynergy, we could follow up serial changes throughout by 2DE.

Thus, it was concluded that 2DE can play an important role for clinical diagnosis of acute cardiovascular diseases, because the method can be performed easily and noninvasively, and can provide valuable information which cannot be obtained by the other existing methods.
\end{abstract}

\section{1.はじめに}

当院では, 循環器救急疾患特に急性心筋梗塞において は数多く経験しているが，一部の例では従来の検査法で ある心電図・血清酵素による診断が困難なことがある. 本法は，従来の診断法では検出が困難な場合でも早期 に壁運動異常を検出することが可能であり，確定診断に 極めて有用である。

緊急超音波検査の対象となる心血管病変としては Fig. 1 に示す如くである.そこで今回は，2.心筋炎，3.急 性心筋梗塞，7.急性大動脈弁閉鎖不全について断層心工 コー法（以下 $2 \mathrm{DE}$ ）が有用と考えられた代表的な症例を
1. 大動脈解離
2. 急性心膜 - 心筋炎
3. 急性心筋梗塞
4. 心夕ンポナーデ
5. 腹部大動脈瘤破裂
6. 心不全
7. 急性大動脈弁閉鎖不全，急性僧帽弁閉鎖不全
8. 肺塞栓
9. 人工弁機能障害

Fig. 1 The indication of emergency echocardiography in cardiovascular diseases. 
呈示する.

\section{2. 対 象}

当院で昭和 56 年 8 月 1 日〜 59 年 5 月 29 日までの過去 2 年10ケ月間に2DEが施行された7084例の内, 循環器救急 疾患は206例で，その内訳はFig. 2に示す如くである。ま ず初めに急性心筋梗塞から症例を呈示する。

\begin{tabular}{|c|c|c|}
\hline 急性心笠梗塞 & 191例 (93\%) & *心室中隔穿孔 4 例 \\
\hline 細菌性心内膜炎 & 5 例 $(2 \%)$ & \\
\hline 梗 & 例 $(2 \%)$ & \\
\hline 解離性大動脈瘤 & 3例 $(1.5 \%)$ & \\
\hline の 他 & 3 例 $(1.5 \%)$ & \\
\hline 計 & 6 例 $(100 \%)$ & \\
\hline
\end{tabular}

Fig. 2 Cardiovascular diseases in which emergency 2DE were undertaken in our hospital. $\quad(1981.8 .1 \sim 1984.5 .29)$

3. 症

例
（1）心電図上はっきりとした所見が得られなかった症 例で2DEを施行した結果，Fig. 3 に示す如く上段が長軸 断層, 下段が短軸断層で各々の拡張期・収縮期を traceし てみると, 左室後壁側の壁運動黑常 (akinesis) が認めら れ急性心筋梗塞と判明, 後に $\mathrm{T} 1$ シンチを施行し左室後 壁の perfusion defect 認めた。

心電図で判定に迷うような純後壁梗塞，脚ブロックを 伴った梗塞，その他の場合に2DEは早期に診断をする上 で有用であった。

(2) 内科にて診察後, 突然ショックとなった患者で心 電図上では下壁梗塞が疑われた。

Fig. 4 は心肺蘇生時の2DE で心臟の周囲に echo free spaceが認められ自由壁破裂と判明した症例です。

このような重篤患者に扔いても，ベットサイドで比較 的容易に検查が施行でき，診断も可能とする上で有用で あった。

（3）初回，食欲不振・発熱その後体重減少を認め呼吸 困難となり当院受診し，収縮期拡張期雑音を聴取したた め2DEを施行した。

\section{UCT (s.58. 2.7.)}

長 軸
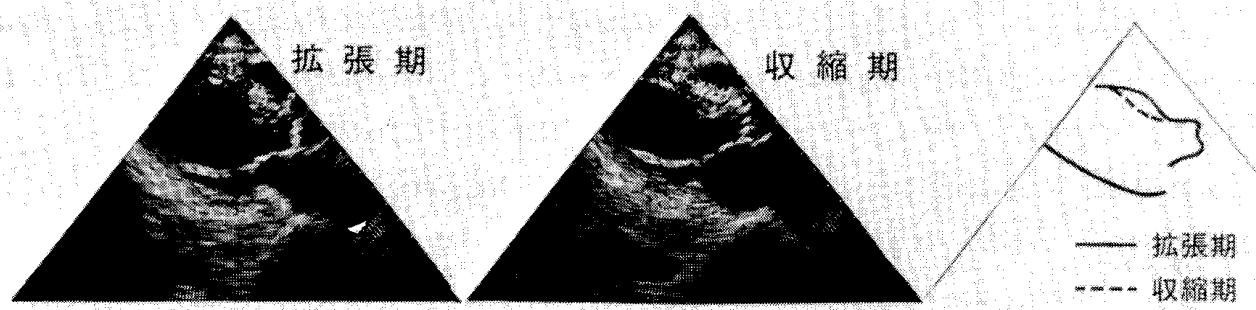

短 軸

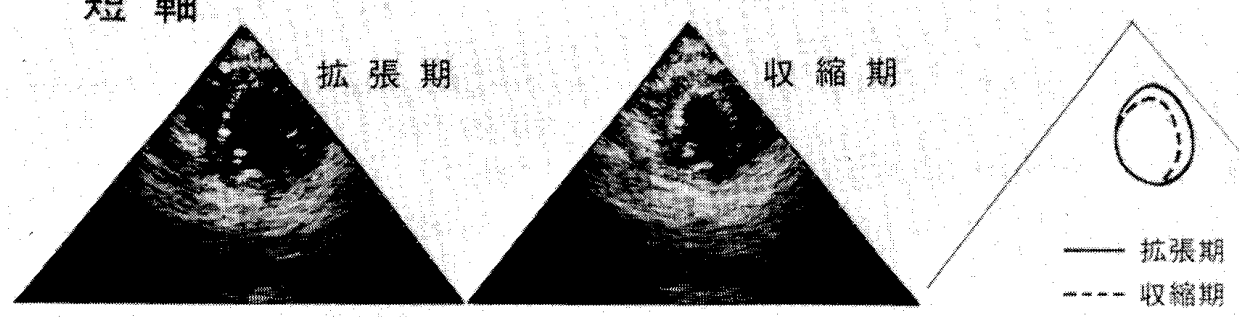

Fig. 3 A case of a myocardial infarction without apparent electrocardiographic changes.

The upper panel shows the parasternal long axis view and the lower panel the short axis view.

The akinesis of the inferoposterior wall motion was easily detected by the endocardial tracing method. 


\section{UCT (s.57.10.14.)}

Short axis view

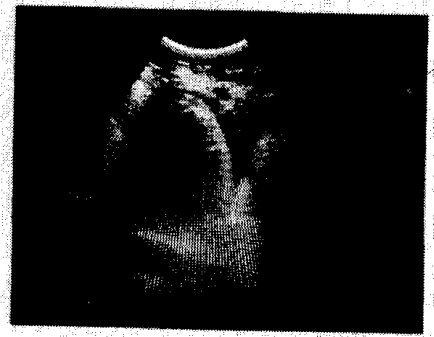

Apical 4-chamber view
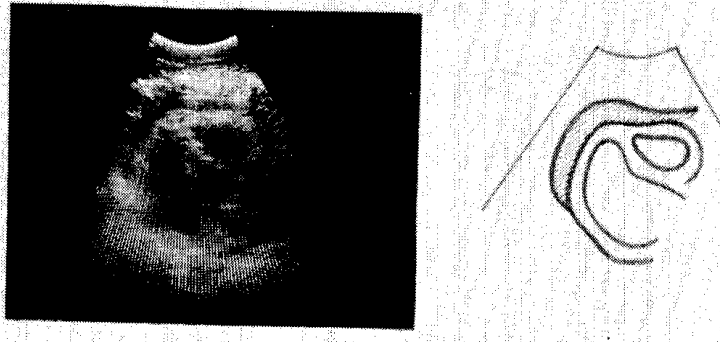

Fig. 4 A case of a cardiogenic shock associated with an acute myocardial infarction. The upper panel (short axis view) and the lower panel (apical four chamber view) demonstrate the echo-free space around the heart.

Hemopericardium by free wall rupture was confirmed by pericardiocentesis and an autopsy.

Fig. 5 の矢印に示す如く大動脈弁は一塊となり収縮期 に大動脈側へ，拡張期に左室流出路へと振子様運動を示 す vegetation が認められ，大動脈弁基部のエコー輝度の 增強が認められた。また，M mode では shaggy echoを とらえている．以上のことから細菌性心内膜炎に基づく 急性大動脈弁閉鎖不全と考元，循環不全も増悪傾向にあ つたため緊急手術を施行した。

その後の経過は良好で術前の血培からも細菌性の心内 膜炎と判明した。

(4) 脈の不整にて来院, 胸部 X 線では異常なく，心電 図にて完全左脚ブロックを認めた。その後, 呼吸困難・ 動悸増強し心室頻拍症および心不全を認め入院となる。 入院後に $2 \mathrm{DE}$ を施行した結果, Fig. 6 に示す如く前壁中 隔の厚みに変化があり，一部では浮腫状のように盛り上 がり奇異性の壁運動異常を呈していたので臨床所見と合 せて限局性心筋炎と考元られた。

そこで心室中隔の動きを M mode 法にて経過を観察
すると, Fig. 7 に示す如く前壁中隔の浮腫によると思わ れる肥厚および奇異性運動が疲痕化と共に徐々に改善さ れていく様子がよくわかる。

以上，2DEが有用と考えられた代表的な症例を呈示し た。

\section{4. 結果}

1）急性心筋梗塞では，心電図で判定に迷うような心 内膜下梗塞, 脚ブロックを伴った梗塞, 純後壁梗塞の場 合に早期に診断をつける上で有用である。

2）急性心筋梗塞の合併症では，心室中隔穿孔・自由 壁破裂・腱索断裂が早期に診断でき，その後の対処も速

\section{症例 13. H.S. 37歳 男性}
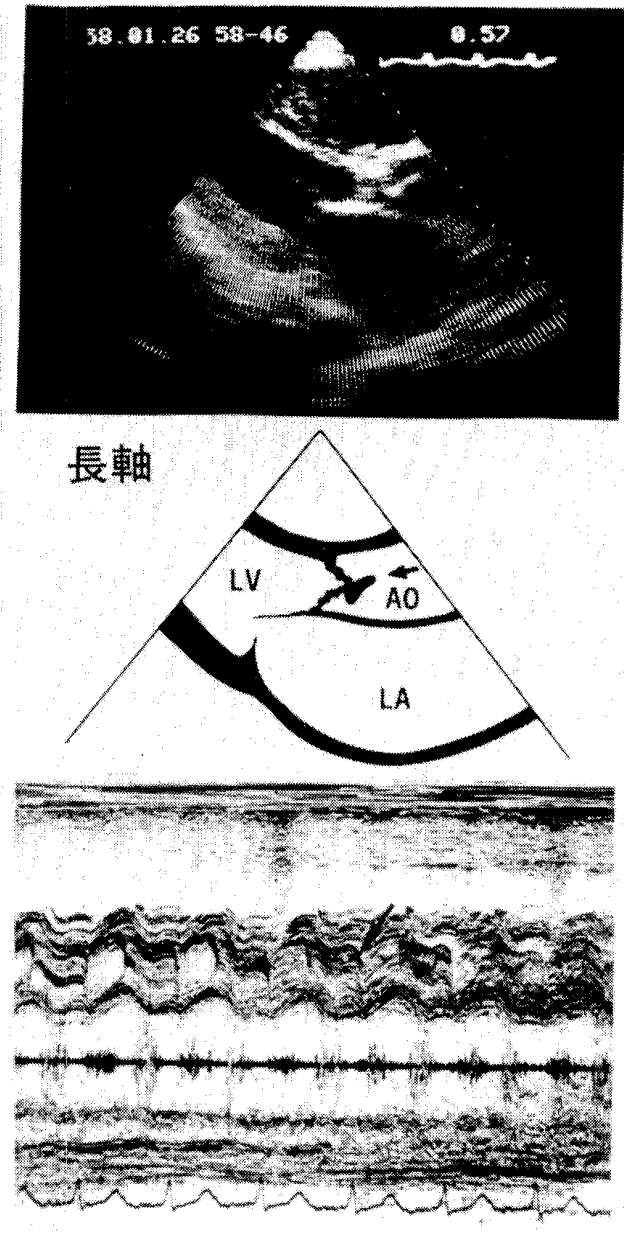

Fig.5 The long axis cross-sectional (upper panel) and $M$ mode (lower panel) were echocardiograms from a patient with bacterial endocalditis.

The vegetations (arrow) were easily detected on the aortic valve. 


\section{心エコー (S.58. 3.23.)}
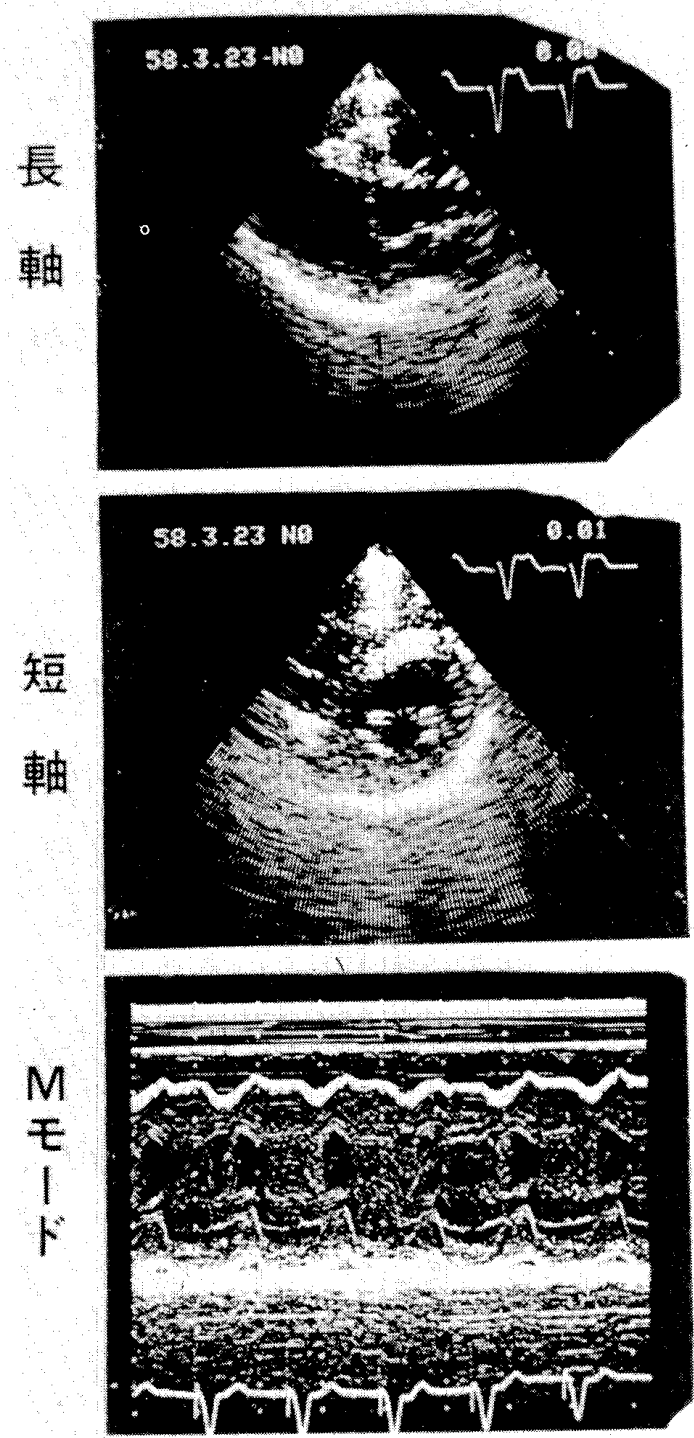

Fig. 6 The upper panel shows the parasternal long axis view and the middle panel shows the short axis view at the papillary muscle level.

The wall thickness of basal interventricular septum appeared to be increased and the motion was dyskinetic. The lower panel ( $\mathrm{M}$ mode echocardiogram) demonstrates the IVS paradoxical motion.

やかとなった。

3）細菌性心内膜炎では，羅患弁の確定診断と障害程 度が推定でき，緊急手術を行う上で有用であった。

4) 心筋炎では, 炎症による浮腫を起し奇異性の壁運 動異常を呈するが，その発症から治瘁までの経過を観察 できる点で有用であった。

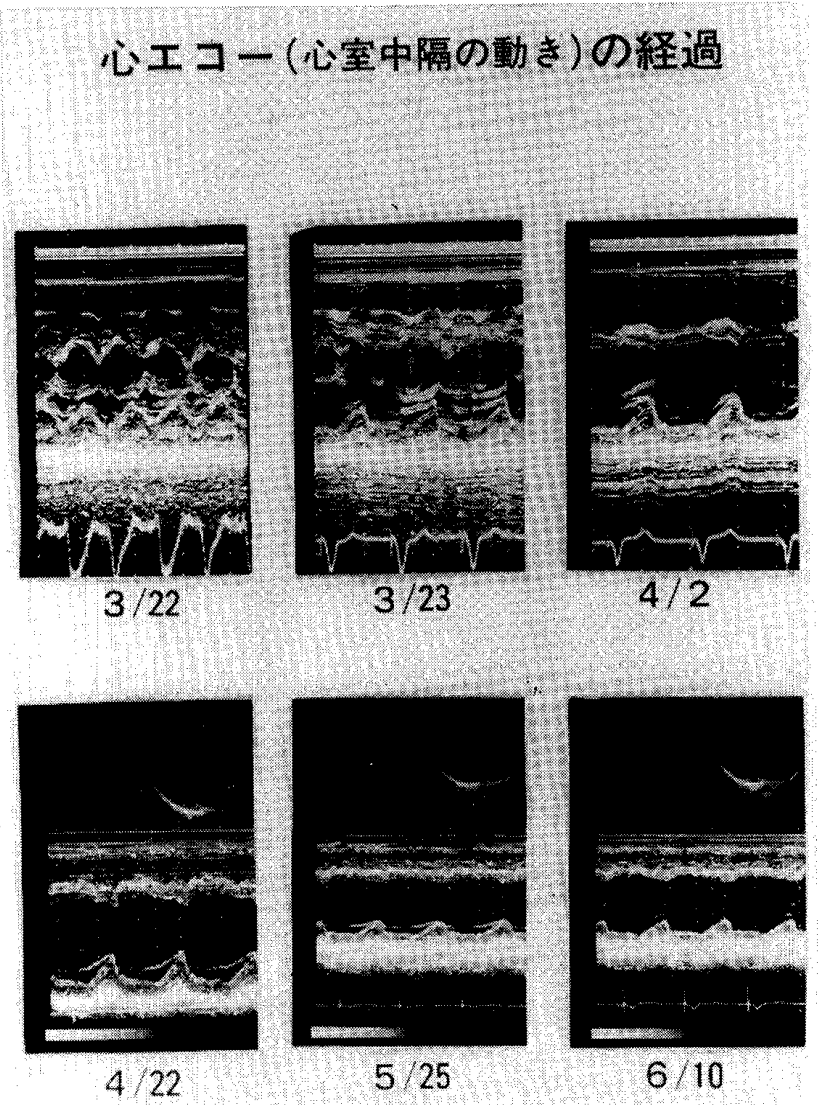

Fig. 7 Serial observation of wall motion asynergy in a patient with acute viral myocarditis.

On March 22 (upper left panel), the interventricular septum (IVS) showed paradoxical motion which persisted until the April 2 (upper right panel). The recovery of IVS wall motion was thickness of IVS has decreased gradually from $10 \mathrm{~mm}$ (March 22) to $7 \mathrm{~mm}$ on the June 10 with increased echo intensity suggesting tissue fibrotic changes.

\section{5. 結論および考察}

以上の如く, $2 \mathrm{DE}$ は緊急を用する急性重症心血管系疾 患に対し従来の検査法では診断不能な症例でも早期診断 を可能とし非観血的，非侵襲的にベットサイドで繰り返 し施行できることから臨床的に優れた検査法である。

また, 近年急性心筋梗塞において PTCR などの治癒法 が盛んに行われているが, その適用の決定, 病態の把握 および経過観察に有用であり，今後の $2 \mathrm{DE} の$ 期待は大き いものと考光る。 